as we have no clinical data, the samples being examined blind by my laboratory. It is also regrettable that we have no experience with sera from patients with suspected venereal disease, making comparison of control group results difficult.

It is obvious from the many studies now carried out that the prediction value of the test is dependent on the sample under test and, while accepting the findings of this investigation, I feel it is still far too early to abandon our work, since examination of the misleading results may well enable modifications to be made to the test procedure to improve its accuracy.

A C Nicholls

Midhurst Medical Research

Institute

Midhurst, Sussex

\section{Urinary tract infections}

SIR,-Allow me to draw attention to two errors in Professor A W Asscher's recent paper on urinary tract infection (UTI) (21 May, p 1332).

In his paragraph on the treatment of UTI in pregnancy Professor Asscher states that displacement of bile salts from plasma protein by sulphonamides may precipitate or exacerbate kernicterus. Clearly the compound liable to such displacement is unconjugated bilirubin and not bile salts as stated.

In discussing some antibiotics best avoided in the treatment of UTI in the presence of renal failure he states that "tetracycline also prevents urea utilisation by the liver and so produces an even greater rise of serum urea concentration." In fact liver (or any other mammalian tissue) never utilises urea, lacking appropriate enzymic resources for this. The elevation of circulating levels of urea observed during treatment with tetracyclines appears to be due to a diminution in protein synthesis in the tissues. The catabolism of amino-acids results in increased urea production in the liver and negative nitrogen balance. Tetracycline may thus be expected to add to the nitrogen loss encountered in other catabolic conditions, such as glucocorticoid treatment.

BRENDAN M BUCKLEY Medical student

University College,

Cork

***We sent a copy of this letter to Professor Asscher, whose reply is printed below.-ED

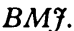

SIR,-I thank Dr Buckley for spotting two inaccuracies in my paper on the treatment of urinary tract infections. "Bile salts" should read "bilirubin" and "urea utilisation" is shorthand for "urea nitrogen reutilisation" by the liver.

Tetracycline by virtue of its antianabolic effect may suppress synthesis of amino-acids from ammonia produced in the gut by hydrolysis of urea by colonic bacteria. This inhibition may lead to increased diversion of ammonia to the urea cycle with a consequent rise in the serum urea concentration. The most important causes of the rise in serum urea during or after tetracycline treatment in patients with kidney failure are natiuresis and vomiting. Since renal function may be permanently harmed I must reiterate that all tetracyclines with the possible exception of doxycycline should be avoided in patients with kidney failure.

William AsSCher

KRUF Institute of Renal Disease

Welsh National School of

Medicine,

Royal Infirmary,

Cardiff

\section{When is significant not significant?}

SIR,-To question the statistical logic of $\mathrm{Si}$ Richard Doll and Mr Richard Peto (4 June, p 1433) is like unto being a feeble Christian among the lions - annihilation is almost certain. Furthermore, as a non-smoking surgeon I am delighted to see that I seem to have something of a chance of immortality. Nevertheless, I must take issue with them for wanting to have their statistical cake and eat it as well. There is no justification whatever for the statement in their summary (not, incidentally, clearly developed or supported in the text of their paper) that "the few other statistically significant associations between occupation and disease were thought to be due to chance. ..." In making such a pronouncement they automatically destroy the logic of practical statistical inference, one of the tenets of which is to say that given a certain probability level we will believe that the results have not arisen by chance. To say that although such a probability level has been achieved we can still choose to ignore it (perhaps because it does not suit the argument) is capricious.

Sir Richard and $\mathrm{Mr}$ Peto must choose. Either they will accept a higher chance probability (for example, 1 in 10 rather than 1 in 20) as a decision rule-and this is not inappropriate in much biological work-or they must leave the matter open, eschewing "thought" which is unaccompanied by the canons of inference.

Hugh Dudley

Surgical Unit,

St Mary's Hospital,
London W2

\section{Role of the occupational health adviser}

SIR,-The letter from Dr J M Goldman (7 May, p 1221) and subsequent correspondence has encouraged me to reminisce.

In 1951, when still a principal in general practice, I obtained an appointment as parttime medical officer to a local government training centre/industrial rehabilitation unitnow renamed "skill centre." By 1958, when I resigned from the NHS, I thought I had learnt a considerable amount about industrial health and "job selection." How wrong I was When engaged fully in multiple part-time appointments in a cross-section of commerce and industry ranging from heavy machinery and smelting to food production and senior executives I soon found that careful observation of individual processes must be among the basic criteria required for assessing suitability for specific types of employment.

In my view Dr Goldman's opinion that the patient's family doctor should decide in all cases whether or not he (or she) is fit for employment can only result in occasional unfortunate situations-perhaps even to the extent of permanent unemployability-which could have been avoided with specialised guidance. Would a general practitioner consider himself better qualified than a surgeon to advise on operative treatment for his patient?

At times I have written, in confidence, to an employee's family doctor or consultant; on rare occasions I have learnt that my letter has been read to the patient. As with Sir Ian Fraser's experience (18 June, p 1599), such responses should be considered only as "occupational hazards" within the medical profession. However deplorable, they are rare, and should not be permitted to detract from the great benefits gained by many through nterchange of professional confidences.

Far too often I find little thought given to the community compared with what some people express as "the rights of the individual." Throughout my quarter-century engaged in occupational health I have maintained the view that when assessing the suitability of an employee for a specific job consideration should be applied, in the following descending priority, to: (1) the employee, (2) the safety of workmates around him, (3) his family, and (4) his employer. How can any medical practitioner not employed in industry be expected to give the same detailed guidance to an employee?

FRED J ROBERTSON

Newcastle upon Tyne

SIR,-I was glad to read Dr R E W Fisher's letter (18 June, p 1599), which puts the record straight in that the employer and the employee are entitled to specialist occupational medical advice from a doctor who is familiar with the patient's work in all its aspects.

The correspondence shows once again the need for better and more comprehensive occupational health services in the UK. If skilled advice is not available to employers many disabled and handicapped persons will be employed in unsuitable work-or not employed at all. Also the person who becomes clinically ill while working is liable to have his employment terminated or fail to be placed in work within his reduced capabilities.

A R BROADBENT

Hanworth, Middx

\section{SOMA}

SIR,-In my previous letter (28 May, p 1409) I merely asked a question of $\mathrm{Mr}$ Saugman In his reply (11 June, p 1538) he has declined to answer the question, which he has interpreted as an allegation. I have made no allegation. I simply asked whether it would be impolite to ask Mr Saugman if his company ever paid authors royalties of more than $12 \frac{1}{2} \%$. Once again he puts his finger on yet another potent reason why the formation of SOMA is opportune: it is precisely because such questions as royalties are not openly discussed that royalties paid by various publishers vary and why it is necessary for authors to pool information so that they may seek the best possible return for their labours.

\section{J T DAviES}

Postgraduate Medical Centre, Raigmore Hospital Inverness

** This correspondence is now closed.-ED, BMY. 